\title{
Sifat Fungsional Pati Ubi Kelapa Kuning (Dioscorea alata) dan Pemanfaatannya sebagai Pengental pada Saus Tomat
}

\author{
Functional Properties of Yellow Greater Yam's Starch (Dioscorea alata) and Its Application as Thickening Agent \\ in Tomato Sauce
}

\author{
U. Ulyarti ${ }^{1 *}$, L. Lavlinesia ${ }^{1}$, N. Nuzula ${ }^{1}$, N. Nazarudin ${ }^{1,2}$ \\ 1Program Studi Teknologi Hasil Pertanian, Fakultas Teknologi Pertanian, Universitas Jambi, \\ Kampus Unja Pondok Meja, Kabupaten Muaro Jambi, Jambi, 36361, Indonesia \\ 2Program Studi Teknik Kimia, Fakultas Teknik, Universitas Jambi, \\ Kampus Unja Mendalo, Kabupaten Muaro Jambi, Jambi, 36361, Indonesia \\ *Email: ulyarti@unja.ac.id
}

Tanggal submisi: 23 Januari 2018; Tanggal penerimaan: 4 Juli 2018

\begin{abstract}
ABSTRAK
Penelitian ini dilakukan untuk mengetahui sifat fungsional pati ubi kelapa kuning (Dioscorea alata) dan mengetahui kemampuannya sebagai pengental pada saus tomat. Penelitian dilakukan dalam 2 tahapan yaitu ekstraksi pati ubi kelapa kuning dan analisis sifat fisik dan fungsionalnya serta percobaan aplikasi pati sebagai pengental pada saus tomat menggunakan rancangan acak lengkap dengan 5 taraf konsentrasi pati $(0,1,2,3$, dan 4\% b/b) dan 4 kali ulangan. Konsentrasi pati dihitung berdasarkan persentase berat pati terhadap berat bubur tomat. Analisis sifat fungsional pati menunjukkan bahwa pati ubi kelapa kuning memiliki kemampuan sebagai pengental namun masih memiliki nilai setback yang cukup tinggi. Konsentrasi pati ubi kelapa kuning berpengaruh nyata terhadap kekentalan, sineresis saus tomat, dan nilai $a^{*}$ saus tomat namun tidak berpengaruh nyata terhadap kadar air, total padatan terlarut, nilai $L^{*}$ dan nilai $b^{*}$ saus tomat. Walaupun terjadi perubahan warna yang jelas dapat dilihat oleh mata manusia $(\Delta \mathrm{E}>3)$, konsentrasi pati sebesar $2 \%$ dapat digunakan dalam pembuatan saus tomat tanpa sineresis selama penyimpanan selama 1 minggu dan memiliki kekentalan 4,85 Poise, total padatan terlarut 44,8 obrix, nilai $L * 50,75, a * 50,75, b * 51,30$ dan penerimaan keseluruhan "agak suka".
\end{abstract}

Kata kunci: Dioscorea alata; pengental; saus tomat; sifat fungsional; ubi kelapa

\begin{abstract}
The aim of this research was to determine the functional properties of yellow greater yam's starch (Dioscorea alata) and its ability to acts as thickening agent for tomato sauce. This research was carried out in 2 stages: starch extraction followed by determination of its physical and functional properties and production of tomato sauce using completely randomized design with 5 levels of starch concentration and 4 replications. The levels were $0,1,2,3$ and $4 \%$ which was calculated from tomato pulps. Functional properties of yellow greater yam's starch showed the capability as thickening agent but had quite high setback value. The result showed that the concentration of yellow greater yam's starch significantly affect viscosity and syneresis $(p<0.01)$ and $a^{*}$ value $(p$ $<0.05$ ) but did not affect water content, total soluble solid, $L^{*}$ and $b^{*}$ of the tomato sauce. Although creates an obvious color difference $(\Delta \mathrm{E}>3)$, the concentration of $2 \%$ yellow greater yam's starch is proposed to be used as thickening agent in tomato sauce producing tomato sauce without syneresis during a week of storage, viscosity 4.85 Poise, total soluble solid 44.8 'brix, $L * 50.75, a * 50.75, b * 51.30$ and overal acceptance "rather like" to "like".
\end{abstract}

Keywords: Dioscorea alata; functional properties; thickening agent; tomato sauce 


\section{PENDAHULUAN}

Ubi kelapa (Dioscorea alata) merupakan tanaman yang belum dibudidayakan secara baik di Propinsi Jambi. Masyarakat kurang menyukai umbi ini karena berasa hambar tidak seperti umbi lainnya seperti singkong, ubi jalar, dan talas. Terdapat setidaknya lima jenis ubi kelapa dengan warna yang berbeda ditemukan di Propinsi Jambi, yaitu ubi ungu muda, ungu tua, putih, kuning dan kuning dengan kulit ungu. Masing-masing ubi memiliki kandungan zat gizi yang berbeda dan kadar utama berupa karbohidrat terutama pati. Tanaman ini memiliki beberapa keunggulan, yaitu potensi produksinya dapat mencapai 40 ton/ha, syarat tumbuh sangat luas dari permukaan laut hingga ketinggian lebih dari $1500 \mathrm{dpl}$, dan mulai dari tanah lembab (rawa) hingga lahan kering (Herison dkk., 2010).

Ekstraksi pati dari beberapa jenis ubi kelapa menghasilkan rendemen yang berbeda dimana ubi kelapa kuning merupakan yang tertinggi $(22,7 \%)$ dibandingkan ubi kelapa ungu $(16,8 \%)$ dan ubi kelapa putih $(19,3 \%)$ (Nadia dan Hartati, 2012). Kandungan pati yang tinggi dalam ubi kelapa kuning merupakan salah satu potensi yang dapat dikembangkan. Pati ubi kelapa mengandung $24-26 \%$ amilosa dan $69-73 \%$ amilopektin serta memiliki kekentalan dan stabilitas termal yang tinggi. Suhu gelatinisasi pati ubi kelapa cukup tinggi yaitu diatas $79{ }^{\circ} \mathrm{C}$ (Nadia dkk., 2014). Menurut Ulyarti dkk. (2016a) pati ubi kuning bahkan memiliki suhu pembentukan pasta $82,9{ }^{\circ} \mathrm{C}$. Oleh sebab itu, pati ini berpotensi untuk digunakan sebagai pengental pada produk yang diolah dengan suhu tinggi seperti saus tomat.

Kekentalan saus tomat merupakan komponen utama kualitas yang menentukan penerimaan konsumen (Bayod dkk., 2008). Walaupun kekentalan saus tomat bisa didapat secara alami melalui pemilihan tingkat kematangan buah, kadar padatan, ukuran partikel dan penggunaan suhu selama proses produksi, kekentalan saus tomat sering dibantu oleh bahan tambahan. Pengental berupa gum seperti xanthan gum banyak digunakan dalam pembuatan saus tomat karena kekentalannya yang sangat baik (Diantom dkk., 2017) namun harganya mahal (Li dan Nie, 2015). Penggunaan pati jagung sebagai pengental saus tomat merupakan salah satu alternatif yang lebih murah namun terkendala sifat retrogradasinya yang menurunkan kualitas saus tomat (Mert, 2012). Retrogradasi tersebut ditunjukkan dengan adanya peningkatan kekentalan yang sangat tinggi selama pendinginan pasta pati jagung. Pengukuran stabilitas pasta selama pendinginan (setback) pati ubi kelapa kuning menunjukkan bahwa pati ubi kelapa kuning memiliki kestabilan yang lebih baik daripada pati jagung yang dilihat dari nilai setback yang cukup rendah sebesar 2147cP (Ulyarti dkk., 2016a). Dengan demikian pati ubi kelapa kuning berpotensi untuk menggantikan pati jagung sebagai pengental saus tomat. Oleh sebab itu dilakukan penelitian ini yang bertujuan untuk mengetahui sifat fungsional pati ubi kelapa kuning serta untuk mengetahui kemampuan pati tersebut menggantikan pati jagung sebagai pengental pada saus tomat.

\section{METODE PENELITIAN}

\section{Bahan dan Alat}

Bahan yang digunakan adalah umbi ubi kelapa (Dioscorea alata) dengan warna umbi kuning yang dipanen di Desa Trimulya Kecamatan Rantau Rasau Kabupaten Tanjung Jabung Timur, Propinsi Jambi. Umur panen umbi tidak diketahui dengan pasti karena tanaman ini tumbuh liar di hutan. Tomat yang digunakan adalah tomat varietas apel dengan warna merah lebih dari $90 \%$ permukaan buah. Alat yang digunakan pada penelitian ini adalah ayakan 170 mesh, RVA, viscotester, $\mathrm{pH}$ meter, hand refractometer, camera, dan color box.

\section{Rancangan Penelitian dan Analisis Statistik}

Penelitian dilakukan dalam dua tahapan. Tahapan pertama adalah ekstraksi pati ubi kelapa kuning yang dilanjutkan dengan analisis sifat fisik dan fungsionalnya. Tahap kedua adalah percobaan penggunaan pati ubi kelapa kuning sebagai pengental saus tomat. Percobaan ini menggunakan Rancangan Acak Lengkap (RAL) dengan perlakuan penambahan pati ubi kelapa kuning yang terdiri dari 5 taraf yaitu $0 \%, 1 \%, 2 \%, 3 \%$, dan $4 \%$. Masing-masing perlakuan diulang sebanyak 4 kali. Data yang didapat pada saus tomat dianalisis menggunakan ANOVA dan apabila didapat adanya pengaruh perlakuan maka dilakukan uji lanjut menggunakan Duncan New Multiple Range Test.

\section{Ekstraksi Pati}

Proses pembuatan pati diawali dengan mensortasi umbi, mengupas kulitnya dan mencucinya hingga bersih. Umbi kemudian dipotong dadu $2 \times 2 \mathrm{~cm}$ dan direndam dalam air panas $60^{\circ} \mathrm{C}$ selama 15 menit. Tahapan ini merupakan proses yang ditambah dari prosedur yang digunakan oleh Nadia dkk. (2014). Potongan umbi kemudian diiris tipis $2-3 \mathrm{~mm}$, dicuci dengan air bersih sebanyak 6 kali untuk menghilangkan lendirnya lalu ditiriskan. Irisan umbi kemudian direndam dalam air garam $15 \%$ selama 30 menit, dicuci dengan air mengalir, direndam kembali di dalam air selama 10 menit dan kemudian dicuci hingga 3 kali. Irisan umbi dihaluskan menggunakan blender dengan perbandingan umbi:air sebesar 1:6. 
Bubur umbi yang dihasilkan disaring menggunakan saringan 170 mesh. Residu yang dihasilkan dihaluskan kembali dengan penambahan air sebanyak 6 kali berat residu dan kemudian disaring kembali. Susu pati hasil penyaringan pertama dan kedua dicampur dan diendapkan selama 6 jam. Endapan yang dihasilkan kemudian dipisah dari supernatannya dan dicuci dengan air dan diendapkan selama 2 jam. Pencucian diulangi hingga didapatkan cairan supernatant yang tidak berwarna. Pati basah yang didapatkan kemudian dikeringkan menggunakan pengering pada suhu $50^{\circ} \mathrm{C}$ selama 6 - 8 jam untuk mendapatkan pati kering. Pati yang sudah kering kemudian dihaluskan dan disaring menggunakan saringan 170 mesh.

\section{Pembuatan Saus Tomat}

Tomat disortasi, dibuang tangkainya dan dicuci serta diblansing pada suhu $80{ }^{\circ} \mathrm{C}$ selama 5 menit. Setelah dingin, kulit tomat dibuang begitu juga dengan bekas melekatnya tangkai buah yang keras. Tomat kemudian dihancurkan menggunakan blender dengan kecepatan sedang selama 3 menit dan disaring untuk memisahkan bijinya.

Ekstrak bumbu dan rempah dibuat dengan cara melarutkan bubuk bawang putih $0,30 \%$, bubuk lada $0,4 \%$, bubuk pala $0,1 \%$, bubuk cengkeh $0,5 \%$, dan bubuk kayu manis $0,05 \%$ ke dalam $40 \mathrm{ml}$ air mendidih. Sebanyak $800 \mathrm{~g}$ bubur tomat ditambahkan pati sesuai perlakuan $(0,1,2,3$, dan $4 \%$ b/b). Konsentrasi bumbu, rempah dan pati dihitung berdasarkan persentase berat bumbu, rempah dan pati terhadap berat bubur tomat (\%b/b). Lalu campuran bubur tomat dan pati tersebut dimasak selama 15 menit pada suhu $85^{\circ} \mathrm{C}$. Selanjutnya ekstrak bumbu dan rempah ditambahkan ke dalam saus, diikuti dengan penambahan gula $8 \%$ dan garam $1,5 \%$ sambil terus dilakukan pemanasan dan pengadukan selama 15 menit pada suhu $80-85^{\circ} \mathrm{C}$. Tahap terakhir yaitu pengemasan saus ke dalam botol kaca yang telah disterilkan. Sterilisasi dilakukan dalam air mendidih selama 30 menit lalu dikeringkan menggunakan oven selama 2 jam pada suhu $120^{\circ} \mathrm{C}$.

\section{Analisis Sifat Fisik dan Fungsional Pati}

Sifat fisik pati yang diukur adalah warna pati yang terdiri dari nilai $L^{*}, a^{*}$, dan $b^{*}$ dianalisis menggunakan metode simple digital imaging (Yam dan Papadakis, 2004; Leon dkk., 2006).

Sifat fungsional yang diukur meliputi sifat pasta (Hughes dkk., 2009), swelling power pati (Mir dan Don Bosco, 2014), daya serap air (water absorption capacity, WAC) dan daya serap minyak (oil absorption capacity, OAC) (Falade dan Christopher, 2015).
Sifat pasta pati ubi kelapa kuning dianalisis menggunakan Rapid Visco Analyser (Newport RVA dengan Thermo Haake K20) dengan konsentrasi pati $7 \%(\mathrm{~b} / \mathrm{v})$ dimana berat pati dihitung berdasarkan berat keringnya (db) (Hughes dkk., 2009). Pada awalnya kecepatan putaran diatur $960 \mathrm{rpm}$ selama 10 detik, kemudian $160 \mathrm{rpm}$ sampai selesai pengamatan. Sampel disetimbangkan pada $50^{\circ} \mathrm{C}$ selama 1 menit kemudian dinaikkan suhunya hingga hingga $95{ }^{\circ} \mathrm{C}$ dengan kecepatan kenaikan suhu $6^{\circ} \mathrm{C} /$ menit. Sampel kemudian didiamkan pada suhu $95{ }^{\circ} \mathrm{C}$ selama 5 menit. Suhu kemudian diturunkan hingga $50{ }^{\circ} \mathrm{C}$ dengan kecepatan penurunan suhu $6^{\circ} \mathrm{C} /$ menit. Pasta kemudian didiamkan pada suhu $50^{\circ} \mathrm{C}$ selama 2 menit.

\section{Kekentalan Saus Tomat}

Kekentalan saus diukur dengan dua cara yaitu menggunakan instrumen dan menggunakan panelis agak terlatih. Kekentalan saus yang diukur menggunakan instrumen Rion Viscotester vt-04 dilakukan pada hari ke-3 dan hari ke-21. Saus sebanyak $200 \mathrm{~mL}$ dimasukkan kedalam gelas beaker $250 \mathrm{~mL}$. Lalu jarum spindel dipasang pada viskotester dan diatur kecepatan putarnya (6 rpm). Selanjutnya sampel diukur kekentalannya dimana kekentalan (Poise) adalah angka pembacaan pada viscotester.

\section{Sineresis Saus Tomat}

Pengukuran sineresis saus dilakukan dengan cara $30 \mathrm{~g}$ saus dimasukkan ke dalam wadah plastik tertutup. Kemudian wadah disimpan selama 7, 14, dan 21 hari. Air yang terpisah dari saus dipisahkan kemudian ditimbang beratnya. Tingkat sineresis dihitung dalam persen berat air yang keluar per berat saus mula-mula.

\section{Total Padatan Terlarut Saus Tomat}

Total padatan terlarut saus tomat diukur dengan menggunakan hand refractometer merek G-WON model GMK-701AC dan dinyatakan dalam ${ }^{\circ}$ Brix. Sebelum pengukuran, saus tomat diencerkan dengan cara diambil sampel sebanyak $1 \mathrm{~g}$ kemudian ditambahkan aquades hingga mencapai $10 \mathrm{~mL}$. Sampel yang telah diencerkan diteteskan pada prisma refraktometer, kemudian diamati layar pembaca skala refraktometer. Angka yang terbaca pada skala kemudian dikali dengan faktor pengenceran untuk mendapatkan ${ }^{\circ}$ Brix.

\section{Warna Saus Tomat}

Warna saus tomat dianalisis menggunakan metode simple digital imaging (Yam dan Papadakis, 2004) dan (Leon, dkk., 2006). Kamera dan lampu 
neon ditempatkan di dalam kotak kayu dengan bagian dalam dicat berwarna hitam untuk menghilangkan latar belakang cahaya. Kamera digital dengan resolusi 4 megapiksel diletakkan vertikal pada jarak $22,5 \mathrm{~cm}$ dari sampel. Empat buah lampu neon Daylight 18 watt lebar $60 \mathrm{~cm}$ ditempatkan pada setiap sisi bagian atas kotak dengan sudut $45^{\circ}$ antara sumbu lensa. Gambar-gambar diambil pada resolusi maksimal (2272 x 1704 piksel). Gambar yang diperoleh diolah dengan menggunakan software Photoshop untuk menampilkan nilai $L^{*} a * b *$.

Keterangan:

$L^{*}=$ kecerahan hitam $(0)$ putih $(100)$

$a^{*}=$ derajat merah $(+80)$ hijau $(-50)$

$b^{*}=$ derajat kuning $(+70)$ biru $(-70)$

Total perubahan warna $\Delta \mathrm{E}$ dihitung menurut Torbica (Torbica, dkk., 2016) menggunakan Persamaan 1.

$$
\Delta E_{x}=\sqrt{\left(\mathrm{L}_{\mathrm{x}}^{*}-\mathrm{L}_{0}^{*}\right)^{2}+\left(\mathrm{a}_{\mathrm{x}}^{*}-\mathrm{a}_{0}^{*}\right)^{2}+\left(\mathrm{b}_{\mathrm{x}}^{*}-\mathrm{b}_{0}^{*}\right)^{2}}
$$

Dimana:

$\Delta \mathrm{E}_{\mathrm{x}}=$ Perubahan warna pada perlakuan $\mathrm{x}$ dibandingkan dengan kontrol

$L^{*}{ }_{x}=$ Nilai kecerahan pada perlakuan $\mathrm{x}$

$L_{0}^{*}=$ Nilai kecerahan pada kontrol (perlakuan $0 \%$ pati)

$a^{*}{ }_{x}=$ Nilai kemerahan hingga kehijauan pada perlakuan $\mathrm{x}$

$a^{*}{ }_{0}=$ Nilai kemerahan hingga kehijauan pada kontrol (perlakuan $0 \%$ pati)

$b^{*}{ }_{x}=$ Nilai kekuningan hingga kebiruan pada perlakuan $\mathrm{x}$

$b^{*}=$ Nilai kekuningan hingga kebiruan pada kontrol (perlakuan $0 \%$ pati)

Nilai yang digunakan untuk menentukan apakah perbedaan warna dapat atau tidak dapat dengan jelas dilihat oleh mata manusia yaitu:

$\Delta \mathrm{E}<1$ menunjukkan perbedaan warna tidak dapat dilihat oleh mata manusia

$1<\Delta \mathrm{E}<3$ menunjukkan perbedaan warna tidak jelas dilihat oleh mata manusia

$\Delta \mathrm{E}<3$ menunjukkan perbedaan warna dengan jelas dapat dilihat oleh mata manusia

\section{Sifat Organoleptik Saus Tomat}

Sifat organoleptik yang dianalisis pada saus tomat meliputi kekentalan yang dianalisis menggunakan uji pembanding jamak dan uji kesukaan terhadap penerimaan keseluruhan. Penilaian dilakukan oleh panelis agak terlatih yaitu dari mahasiswa Program Studi Teknologi Hasil Pertanian Universitas Jambi sebanyak 18 orang. Sampel yang akan diuji disiapkan di atas meja dengan wadah disertai dengan sampel baku (R) yang merupakan saus dengan merk dagang "Sasa". Penerimaan keseluruhan saus tomat dinilai dengan menggunakan skala hedonik 1 sampai 5 . Skor penilaian kekentalan dan penerimaan keseluruhan dapat dilihat pada Tabel 1.
Tabel 1. Skor penilaian uji perbandingan jamak dengan saus tomat komersil $(R)$ dan penilaian keseluruhan saus tomat

\begin{tabular}{cll}
\hline Skor & \multicolumn{1}{c}{ Kekentalan } & Penilaian keseluruhan \\
\hline 1 & Sangat lebih encer dari R & Tidak suka \\
2 & Lebih encer dari R & Agak tidak suka \\
3 & Agak encer dari R & Agak suka \\
4 & Sama kental dengan R & Suka \\
5 & Agak lebih kental dari R & Sangat suka \\
6 & Lebih kental dari R & \\
7 & Sangat lebih kental dari R & \\
\hline
\end{tabular}

\section{HASIL DAN PEMBAHASAN}

\section{Sifat Fungsional Pati}

Profil RVA pati ubi kelapa kuning menggambarkan perubahan kekentalan pasta selama pemanasan dan pendinginan di bawah kondisi pengadukan konstan (Gambar 1). Terjadi peningkatan kekentalan secara drastis pada suhu $82{ }^{\circ} \mathrm{C}$ diikuti dengan kekentalan puncak yang dicapai pada suhu $95^{\circ} \mathrm{C}$. Pada awal periode pemanasan konstan pada suhu $95{ }^{\circ} \mathrm{C}$ terjadi penurunan kekentalan dan pada akhir periode ini kekentalan pasta meningkat kembali. Profil RVA pati ini mirip dengan yang telah dipublikasi sebelumnya (Nadia dkk., 2014; Huang dkk., 2006). Pati Dioscorea alata ubi kuning hasil penelitian ini memiliki suhu pembentukan pasta $81,7^{\circ} \mathrm{C}$ dan setback 3651 cP (Tabel 1). Setback merupakan salah satu nilai yang menunjukkan proses retrogradasi pati. Semakin tinggi nilai setback maka semakin besar kecenderungan pati tersebut untuk mengalami retrogradasi. Suhu pembentukan pasta dan setback pati ubi kelapa kuning pada penelitian ini lebih rendah dari yang pernah dilaporkan sebelumnya yaitu $83,95{ }^{\circ} \mathrm{C}$ dan $335,51 \mathrm{RVU}$ atau setara $4020 \mathrm{cP}$ (Nadia dkk., 2014). Nilai setback pati ubi kelapa kuning dalam penelitian ini diketahui lebih tinggi daripada nilai setback pati yang sama namun yang diekstrak setelah perlakuan blansing uap dan pengeringan

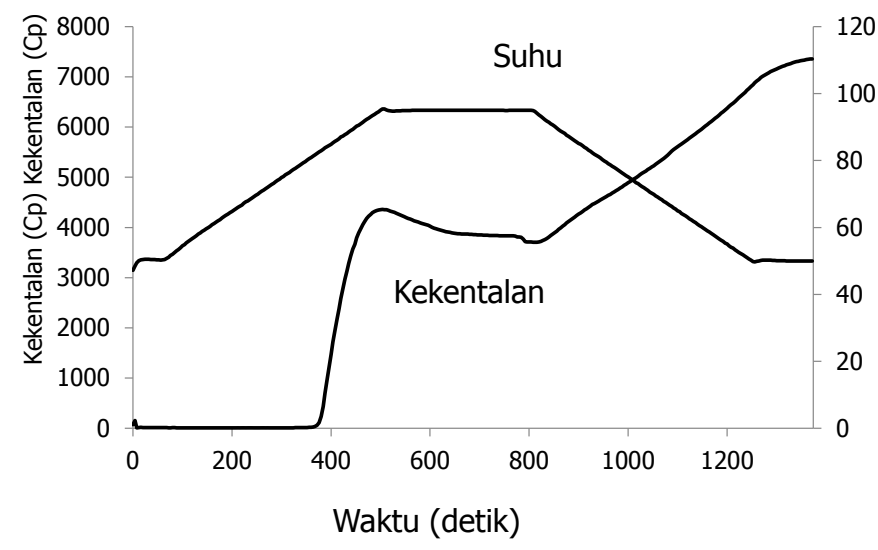

Gambar 1. Profil RVA pati Dioscorea alata umbi kuning 
Tabel 2. Sifat fungsional pati Dioscorea alata ubi kuning

\begin{tabular}{lll}
\hline Sifat pati & & \multicolumn{1}{c}{ Nilai } \\
\hline Sifat pasta & Breakdown & $653 \mathrm{cP}$ \\
pati & Kekentalan final & $7356 \mathrm{cP}$ \\
& Setback & $3651 \mathrm{cP}$ \\
& Suhu pasting & $81,7{ }^{\circ} \mathrm{C}$ \\
Warna pati & $L^{*}$ & $92,2 \pm 0,8$ \\
& $a^{*}$ & $4,6 \pm 0,5$ \\
& $b^{*}$ & $12,8 \pm 0,4$ \\
Swelling & $65^{\circ} \mathrm{C}$ & $2,34(\mathrm{~g} / \mathrm{g})$ \\
power & $85^{\circ} \mathrm{C}$ & $10,62(\mathrm{~g} / \mathrm{g})$ \\
Daya serap air & & $99,48 \pm 35,70(\%)$ \\
Daya serap & & $102,88 \pm 8,26(\%)$ \\
minyak & & \\
\hline
\end{tabular}

yaitu 2147 sd 2705 cP (Ulyarti dkk., 2016a). Blansing uap dan pengeringan pada umbi sebelum ekstraksi dapat mengakibatkan pati tergelatinisasi sebagian yang dapat menurunkan pelarutan pati terutama amilosa keluar dari granula pati (Gunaratne dan Hoover, 2002). Diketahui bahwa penurunan solubilisasi amilosa dapat mengurangi terjadinya retrogradasi pada pasta pati (Bello dkk., 1995).

Warna pati hasil ekstraksi masih menunjukkan adanya warna umbi yaitu kekuningan, namun nilai $L^{*}$ sebesar 92,2 telah menunjukkan tingkat kemurnian pati yang baik (Boudries dkk., 2009). Swelling power (SP) pati ubi kelapa kuning cukup tinggi (Tabel 2) menandakan kemampuan pati sebagai pengental. Nilai SP ini lebih tinggi dibandingkan dengan penelitian sebelumnya dimana pati ubi kelapa kuning memiliki SP $1,97 \mathrm{~g} / \mathrm{g}$ pada suhu $65^{\circ} \mathrm{C}$ (Ulyarti dkk., 2016b) dan sebesar $1,96 \mathrm{~g} / \mathrm{g}$ pada suhu $65^{\circ} \mathrm{C}$ dan $6,76 \mathrm{~g} / \mathrm{g}$ pada suhu $85^{\circ} \mathrm{C}$ (Huang dkk., 2010). Perbedaan SP berkaitan dengan perbedaan kadar amilopektin sementara amilosa bertindak sebagai inhibitor pembengkakan. SP merupakan ukuran kemampuan pati untuk mengalami hidrasi dibawah kondisi tertentu seperti kadar air dan suhu. SP yang tinggi merupakan indikasi lemahnya ikatan didalam granula pati (Mir dan Don Bosco, 2014).

Daya serap air (WAC) menggambarkan struktur granula pati yang memiliki tempat-tempat pengikatan air diluar kemampuan pati untuk berikatan melalui ikatan hidrogen atau ikatan kovalen antar rantai molekul pati. WAC pati ubi kelapa kuning dalam penelitian ini berada dalam kisaran WAC pati beras (Falade dan Christopher, 2015), namun sangat rendah dibandingkan dengan pati beberapa tanaman dioscorea (Jiang dkk., 2013). Daya serap minyak (OAC) menggambarkan kemampuan emulsifikasi pati dalam formulasi produk. Nilai OAC pati ubi kelapa kuning dalam penelitian ini menunjukkan adanya tempat-tempat didalam granula pati yang memiliki area hidrofobik. Selain itu, warna pati yang masih berwarna kekuningan diduga merupakan petunjuk adanya komponen selain pati yang bersifat hidrofobik yang dapat mengikat minyak.

\section{Kekentalan Saus Tomat}

Hasil ANOVA menunjukkan nilai kekentalan saus tomat dipengaruhi oleh konsentrasi pati yang digunakan $(p<0,01)$. Pati ubi kelapa kuning walaupun memiliki kemampuan mengentalkan yang baik, masih memiliki kelemahan pada kemampuan mempertahankan kekentalan tersebut selama penyimpanan yang dapat dilihat dari penurunan nilai kekentalan saus selama 18 hari (Tabel 3). Panelis uji organoleptik menilai bahwa kekentalan saus tomat dengan konsentrasi penambahan pati diantara 2\% dan 3\% sama dengan saus referensi. Penggunaan pengental berupa pati alami seperti umbi ganyong dan singkong sebesar $3 \%$ menghasilkan kekentalan yang lebih rendah daripada pati ubi kelapa kuning dengan konsentrasi yang sama yaitu sebesar 1,6 dan 3,9 poise. Namun demikian, penurunan kekentalan setelah penyimpanan selama 8 minggu lebih kecil yaitu menjadi 1,4 dan 2,7 poise atau sebesar $12,5 \%$ untuk pati canna dan $28,7 \%$ untuk pati singkong (Thaunkhong dkk., 2014).

\section{Padatan Terlarut, Sineresis dan Kadar Air Saus Tomat}

Menurut Haley dan Smith (2003), konsistensi saus yang berkaitan dengan kekentalan saus memiliki korelasi dengan densitas optik saus tomat sementara densitas optik saus memiliki korelasi yang tinggi dengan kadar padatan tidak terlarut. Dalam hal ini, pati ubi kelapa kuning sebagai komponen yang dapat terlarut (dalam proses menggunakan panas) mempengaruhi kekentalan saus tomat bukan karena keberadaannya sebagai bahan padatan namun lebih karena sifat pseudoplastiknya yang mengikat air selama proses pemanasan. Hal ini diperjelas dengan hasil pengamatan total padatan terlarut saus tomat dimana konsentrasi pati yang digunakan sebagai pengental tidak berpengaruh nyata terhadap total padatan terlarut dan kadar air saus tomat $(p>0,05)$. Pengaruh konsentrasi pati ubi kelapa kuning pada kekentalan tanpa diikuti dengan pengaruhnya pada total padatan terlarut dan kadar air menunjukkan ada faktor lain yang berpengaruh pada kekentalan.

Tabel 3. Nilai rata kekentalan saus tomat pada berbagai penambahan pati ubi kelapa kuning

\begin{tabular}{ccccc}
\hline $\begin{array}{c}\text { Penambahan } \\
\text { pati (\%) }\end{array}$ & \multicolumn{2}{c}{$\begin{array}{c}\text { Kekentalan hari } \\
\text { ke- (Poise) }\end{array}$} & $\begin{array}{c}\% \\
\text { Penurunan } \\
\text { kekentalan }\end{array}$ & $\begin{array}{c}\text { Organoleptik } \\
\text { kekentalan }^{1)}\end{array}$ \\
\hline 0 & $1,88^{\mathrm{a}}$ & $1,65^{\mathrm{a}}$ & $12,6^{\mathrm{a}}$ & $1,61^{\mathrm{a}}$ \\
1 & $2,56^{\mathrm{ab}}$ & $2,28^{\mathrm{a}}$ & $12,7^{\mathrm{a}}$ & $2,05^{\mathrm{b}}$ \\
2 & $6,91^{\mathrm{bc}}$ & $4,85^{\mathrm{a}}$ & $23,9^{\mathrm{ab}}$ & $3,50^{\mathrm{c}}$ \\
3 & $12,63^{\mathrm{c}}$ & $8,38^{\mathrm{ab}}$ & $28,4^{\mathrm{ab}}$ & $5,16^{\mathrm{d}}$ \\
4 & $19,00^{\mathrm{c}}$ & $13,25^{\mathrm{b}}$ & $33,5^{\mathrm{b}}$ & 6,50 \\
\hline
\end{tabular}


Faktor tersebut bisa berupa ukuran partikel yang tidak homogen (Bayod dkk., 2008) yang muncul karena tidak adanya homogenisasi bubur tomat setelah diblender dan tidak ada homogenisasi setelah penambahan pati.

Konsentrasi pati berpengaruh sangat nyata terhadap sineresis saus tomat selama penyimpanan (Tabel 4). Diketahui bahwa seperti halnya konsentrasi hidrokoloid, konsentrasi pati berpengaruh pada besar retensi air dalam bahan pangan (Varela dkk., 2003). Semakin tinggi konsentrasi pati ubi kelapa yang digunakan sebagai pengental maka semakin besar sineresis yang terjadi pada saus selama penyimpanan. Hasil ini sejalan dengan terjadinya perubahan kekentalan pada saus tomat selama penyimpanan yang terjadi akibat retrogradasi pati. Retrogradasi pati mengakibatkan keluarnya air pada jaringan amilosa dan amilopektin yang sebelumnya terbentuk selama proses pemasakan saus.

\section{Warna Saus Tomat}

Beberapa parameter warna digunakan untuk melihat pengaruh penggunaan pati pada berbagai konsentrasi terhadap warna asli saus tomat. Warna asli saus tomat dipresentasikan sebagai saus tomat tanpa penambahan pati (Gambar 2). Hasil analisis ragam menunjukkan bahwa perlakuan konsentrasi pati tidak memberikan pengaruh terhadap nilai $L *$ dan nilai $b *$ saus tomat $(p>0,05)$ tetapi berpengaruh nyata terhadap nilai a* $(p<0,05)$. Nilai $\Delta \mathrm{E}$ saus tomat dengan penambahan $1 \%$ sd $4 \%$ semuanya diatas 3 memiliki arti bahwa terjadi perbedaan warna yang dengan jelas dapat dilihat mata manusia diantara saus yang tidak menggunakan pati dan yang menggunakan pati (Torbica dkk., 2016). Nilai rata-rata $L^{*}, a^{*}, b^{*}$ dan $\Delta \mathrm{E}$ saus tomat selengkapnya dapat dilihat pada Tabel 5 .

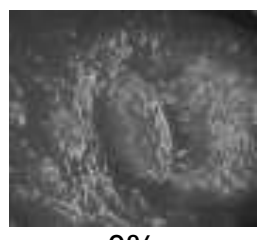

$0 \%$

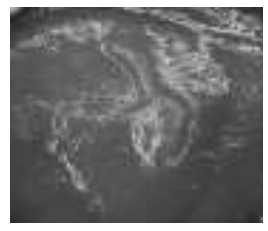

$3 \%$

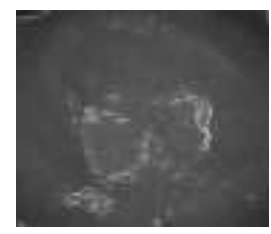

$1 \%$

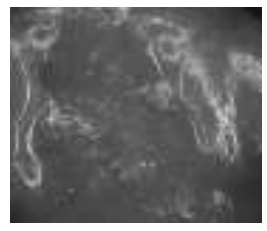

$4 \%$
Gambar 2. Saus tomat yang dibuat dengan beberapa konsentrasi pati ubi kelapa kuning
Tabel 4. Rata-rata sineresis, TPT dan kadar air saus tomat pada berbagai penambahan pati ubi kelapa kuning

\begin{tabular}{|c|c|c|c|c|c|}
\hline \multirow{2}{*}{$\begin{array}{c}\text { Penambahan } \\
\text { pati }(\%)\end{array}$} & \multicolumn{3}{|c|}{ (\%) Sineresis hari ke- } & \multirow{2}{*}{$\begin{array}{l}\text { TPT } \\
{ }^{\circ} \text { Brix }\end{array}$} & \multirow{2}{*}{$\begin{array}{c}\text { Kadar air } \\
(\%)\end{array}$} \\
\hline & 7 & 14 & 21 & & \\
\hline 0 & $0,00^{\mathrm{a}}$ & $0,00^{\mathrm{a}}$ & $0,00^{a}$ & $44,0^{a}$ & $48,58^{\mathrm{a}}$ \\
\hline 1 & $0,00^{a}$ & $0,00^{\mathrm{a}}$ & $0,00^{\mathrm{a}}$ & $44,8^{a}$ & $47,13^{\mathrm{a}}$ \\
\hline 2 & $0,00^{a}$ & $0,31^{a}$ & $0,31^{a}$ & $45,0^{a}$ & $46,57^{a}$ \\
\hline 3 & $4,49^{b}$ & $4,57^{b}$ & $4,57^{b}$ & $47,5^{a}$ & $45,61^{a}$ \\
\hline 4 & $2,64^{c}$ & $2,64^{c}$ & $2,64^{c}$ & $47,5^{a}$ & $45,41^{\mathrm{a}}$ \\
\hline
\end{tabular}

Keterangan: angka yang diikuti huruf kecil yang sama pada kolom yang sama menunjukkan tidak berbeda nyata pada taraf $5 \%$ menurut uji DNMRT.

Tabel 5. Nilai rata-rata $\mathrm{L} *$, $\mathrm{a} *$ dan $\mathrm{b} *$ dan $\Delta \mathrm{E}$ saus tomat yang dibuat dengan beberapa konsentrasi pati ubi kelapa kuning

\begin{tabular}{ccclc}
\hline $\begin{array}{c}\text { Konsentrasi } \\
\text { pati (\%) }\end{array}$ & $\mathrm{L}^{*}$ & $\mathrm{a}^{*}$ & $\mathrm{~b}^{*}$ & $\Delta \mathrm{E}$ \\
\hline 0 & $52,25^{\mathrm{a}}$ & $56,25^{\mathrm{a}}$ & $52,00^{\mathrm{a}}$ & - \\
1 & $50,50^{\mathrm{a}}$ & $52,00^{\mathrm{ab}}$ & $48,75^{\mathrm{a}}$ & $7,62^{\mathrm{a}}$ \\
2 & $50,75^{\mathrm{a}}$ & $50,75^{\mathrm{b}}$ & $51,30^{\mathrm{a}}$ & $8,25^{\mathrm{a}}$ \\
3 & $50,75^{\mathrm{a}}$ & $51,25^{\mathrm{b}}$ & $50,30^{\mathrm{a}}$ & $8,89^{\mathrm{a}}$ \\
4 & $51,00^{\mathrm{a}}$ & $48,75^{\mathrm{b}}$ & $49,30^{\mathrm{a}}$ & $9,89^{\mathrm{a}}$ \\
\hline
\end{tabular}

Tabel 6. Nilai rata-rata organoleptik hedonik saus tomat

\begin{tabular}{cc}
\hline $\begin{array}{c}\text { Pati ubi kelapa kuning } \\
(\%)\end{array}$ & Penerimaan keseluruhan \\
\hline 0 & $2,28^{\mathrm{a}}$ \\
1 & $2,17^{\mathrm{a}}$ \\
2 & $3,50^{\mathrm{b}}$ \\
3 & $3,39^{\mathrm{b}}$ \\
4 & $2,44^{\mathrm{a}}$ \\
\hline
\end{tabular}

Keterangan: angka yang diikuti huruf kecil yang sama tidak berbeda nyata pada taraf $5 \%$ menurut uji DNMRT

Ket: (5) sangat suka. (4) suka (3) agak suka (2) agak tidak suka (1) tidak suka

\section{Penerimaan Keseluruhan Saus Tomat}

Konsentrasi pati berpengaruh sangat nyata terhadap penerimaan keseluruhan saus tomat (Tabel 6). Konsentrasi pati ubi kelapa kuning $2 \%$ dan $3 \%$ menghasilkan penerimaan konsumen yang paling tinggi "agak suka". Penerimaan konsumen sangat berkaitan dengan kekentalan saus (Bayod dkk., 2008). Apabila dibandingkan dengan hasil uji organoleptik kekentalan, maka dapat dinyatakan bahwa kekentalan yang disukai oleh panelis berada pada rentang "agak lebih tidak kental" dari saus referensi hingga "agak lebih kental" dari saus referensi. Besaran konsentrasi pati sebesar 2-3\% adalah rentang konsentrasi pati yang bisa digunakan dalam produksi saus tomat (Juszczak dkk., 2013). 


\section{KESIMPULAN}

Pati ubi kelapa kuning memiliki kemampuan sebagai thickening agent ditunjukkan dengan nilai swelling power dan kekentalan final yang tinggi dan namun tidak stabil selama penyimpanan dilihat dari masih tingginya nilai setback pasta pati. Konsentrasi pati ubi kelapa kuning berpengaruh sangat nyata terhadap kekentalan dan sineresis $(p<0,01)$ berpengaruh nyata terhadap nilai $a^{*}$ saus tomat $(p<0,05)$ namun tidak berpengaruh nyata terhadap kadar air, total padatan terlarut, nilai $L^{*}$ dan $b^{*}$ saus tomat $(p<0,05)$. Walaupun nilai kekentalan masih lebih rendah daripada saus referensi, konsentrasi pati ubi kelapa kuning sebesar $2 \%$ dapat digunakan sebagai pengental saus tomat yang menghasilkan saus tanpa sineresis selama penyimpanan 7 hari, memiliki kekentalan 4,85 Poise, total padatan terlarut 44,8 ${ }^{\circ}$ brix dan penerimaan konsumen "agak suka", namun dengan perubahan warna yang dapat dideteksi oleh mata manusia (nilai $\Delta \mathrm{E}>3$ ).

\section{UCAPAN TERIMA KASIH}

Terima kasih kepada Dekan Fakultas Teknologi Pertanian Universitas Jambi yang telah memberi dukungan dana penelitian melalui skema PNBP Fakultas. Terima kasih kepada Setiawati yang telah membantu pekerjaan teknis selama penelitian.

\section{DAFTAR PUSTAKA}

Bayod, E., WIllers, E., \& Tornberg, E. (2008). Rheological and structural characterization of tomato paste and its influence on the quality of ketchup. LWT , 1289-13000.

Bello, A., Waniska, R., Gomez, M., \& Rooney, I. (1995). Starch solubilisation and retrogradation during preparation of To (a food gel) from different sorghum cultivars. Cereal Chemistry, 80-84.

Diantom, A., Curti, E., Cartini, E., \& Vittadini, E. (2017). Effect of added ingredients on water status and physicochemical properties of tomato sauce. Food Chemistry , http://dx.doi.org//10.1016//j.foodchem.2017.01.160.

Falade, K., \& Christopher, A. (2015). Physical, functional, pasting and thermal properties of flours and starches of six Nigerian rice cultivars. 44,. Food Hydrocolloids. , 478-490.

Gunaratne, A., \& Hoover, R. (2002). Effect of heat-moisture treatment on the structure and physicochemical properties of tuber and root starches. Carbohydrate Polymers, 425-437.

Haley, T., \& Smith, R. (2003). Evaluation og in line absorption photometry to predict consistency of concentrated tomato products. LWT , 159-164.
Herison, C., Turmudi, E., \& Handajaningsih, M. (2010). Studi Kekerabatan Genetik Aksesi Uwi (Dioscorea spp) yang dikoleksi dari Beberapa Daerah di Pulau Jawa dan SUmatera. Akta Agrosia, 13(1), 55-61.

Huang, C.-C., Lai, P., Chen, I.-H., Liu, Y.-F., \& Wang, C.-C. (2010). Effects of mucilage on the thermal and pasting properties of yam, taro, and sweet potato starches. LWT-Food Science and Technology , 849-895.

Huang, C.-C., Lin, M.-C., \& Wang, C.-C. (2006). Carbohydrate polymers , 524-531.

Hughes, T., Hoover, R., Liu, Q., Donner, E., Chibbar, R., \& Jaiswal, S. (2009). Composition, morphology, molecular structure, and physicochemical properties of starches from newly released chickpea (Cicer arietinum L.) cultivars grown in Canada. Food Reseach International , 627-635.

Jiang, Q., Gao, W., Shi, Y., Li, X., Wang, H., Huang, L., et al. (2013). Physicochemical properties and in vitro digestion of starches from different Dioscorea plants. Food Hydrocolloids, 432-439.

Juszczak, L., oczadly, Z., \& Galkowska, D. (2013). Effect of modified starches on rheological properties of ketchups. Food Bioprocess Technol , 1251-1260.

Leon, K., Mery, D., Pedreschi, F., \& Leon, J. (2006). Color Measurement in L*a*b* units from RGB Digital Images. Food Research International, 39 , 1084-1091.

Li, j.-M., \& Nie, S.-P. (2015). The functional and nutritional aspects of hydrocolloid in foods. Food Hydrocolloid, doi:10.1016/j.foodhyd.2015.01.035.

Mert, B. (2012). Using high pressure fluidization to improve physical properties and lycopene content of ketchup type product. Journal of Food Engineering , 579-587.

Mir, A. S., \& Don Bosco, S. J. (2014). Cultivar difference in physicochemical properties of starches and flours from temperate rice of Indian Himalayas. Food Chemistry , 448-456.

Nadia, L., \& Hartati, A. (2012). Potensi Umbi Uwi Ungu sebagai Bahan Pangan dan Khasiatnya sebagai Bahan Fungsional. Jakarta: Universitas Terbuka.

Nadia, L., Wirakartakusumah, M. A., Andarwulan, N., Purnomo, E. H., Koaze, H., \& Noda, T. (2014). Characterization of physicochemical and functional properties of starch from five yam (Dioscorea Alata)cultivars in Indonesia. International Journal of Chemical Engineering and Aplications , 489-496.

Thaunkhong, K., Uttapap, D., Puncha-arnon, S., Rungsardthong, V., \& Puttanlek, C. (2014). Application of native and modified canna starches as thickening agent in tomato sauces. KMUTT Research and Development Journal , 4659.

Torbica, A., Belovic, M., Mastilovic, J., Kevresan, Z., Pestoric, M., Skrobot, D., et al. (2016). Nutritional, rheological, and sensory evaluation of tomato ketchup with increased 
content of natural fibres made from fresh tomato pomace. Food and Bioproducts Processing , 299-309.

Ulyarti, U., Nazarudin, N., Fortuna, D., Lavlinesia, L., \& Surhaini, S. (2016a). Methods of extraction affects pasting properties of Dioscorea alata's starch. Green Development International Conference (hal. 98-100). Jambi: Lembaga Penelitian dan Pengabdian Kepada Masyarakat Universitas Jambi.

Ulyarti, Lavlinesia, Fortuna, D., \& Surhaini. (2016b). The study of physical properties of Dioscorea alata's starch from Jambi Province. IJASEIT , 456-459.
Varela, P., Gambaro, A., Gimenez, A., Duran, I., \& Lema, P. (2003). Sensory and instrumental texture measures on ketchups made with different thickeners. Journal of Texture Studies, 317-330.

Yam, K., \& Papadakis, S. (2004). A Simple Digital Imaging Method for Measuring and Analysing Color of Food Surfaces. Journal of Good Engineering, 61 , 61 (137142), 137-142. 